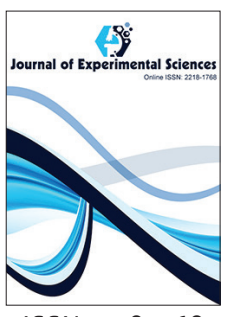

ISSN: $2218-1768$
Received: 23-06-2020 Revised: $16-08-2020$ Accepted: 30-08-2020 Published: 05-09-2020

*Corresponding author: Wouokoue Taffo Junior Baudoin

Email:junior.baudoin@ yahoo.fr

\section{Floristic diversity and management of fodder resources of the natural pastures of the Savanna Highlands of Western Cameroon}

\author{
Wouokoue Taffo Junior Baudoin ${ }^{*}$, Avana Tientcheu Marie Louise², \\ Hamawa Yougouda3 , Nguetsop Victor Francois', Tsobou Roger ${ }^{4}$, \\ Ngnignindiwou Mouncharou Jonathan ${ }^{4}$
}

\begin{abstract}
'Department of Biological Sciences, Faculty of Science, University of Maroua, P.O Box 814 Maroua, Cameroun, 2Department of Forestry, Faculty of Agronomy and Agricultural Sciences, University of Dschang, Dschang, Cameroon, ${ }^{3}$ Département d'Agriculture, Elevage et Produits Dérivés, Ecole Nationale Supérieure Polytechnique, Université de Maroua, B.P 46 Maroua, Cameroun, ${ }^{4}$ Department of Plant Biology, Faculty of Science, University of Dschang, P.O Box 67, Dschang
\end{abstract}

\begin{abstract}
Sustainable management of pastoral resources requires knowledge in terms of floristic diversity and productivity of the rangelands. The objective of the present study carried out in the Bamboutos Mountains was to assess the floristic diversity and carrying capacity of the natural pastures. Floristic inventory was done using the method of quadrat point aligned in 15 plots of $400 \mathrm{~m}^{2}$. Aerial phytomass of herbaceous plants was measured by the full harvest method. A total of 74 species, including 09 woody plants belonging to 56 genera and 20 families were recorded. The number of taxa recorded in the plots varied from 11 to 36 species. Imperata cylindrica with a specific contribution of presence of $17.45 \%$ was the most abundant species in the rangeland. The species-richest families were Poaceae, Fabaceae, Asteraceae and Cyperaceae. The calculated pastoral value of the pasture was $56.21 \%$. These pastures were dominated by phanerophytes (29.72\%) and therophytes (24.32\%). The forage productivity of the grazed area, estimated based on the regrowth biomass was $6498.57 \mathrm{~kg} \mathrm{DM} / \mathrm{ha}$ while the carrying capacity of the rangeland was $2.31 \mathrm{TLU} / \mathrm{ha}$. These results showed that the fodder potential of the Bamboutos Mountains is enough diversified but remains under exploited.
\end{abstract}

KEYWORDS: Herbaceous vegetation, pastoral value, aerial phytomass, carrying capacity, Bamboutos Mountains

\section{INTRODUCTION}

Savannahs ecosystems in Africa are mainly exploited for agricultural activities including pastoralism [1]. In Cameroon, savannahs lands are extensively used for cattle, sheep and goat rearing, whose productivity should strongly depend on rational and sustainable pasture management. In such production systems, the herdsman interventions are mainly restricted to watching the animals while their feeds depend essentially on the exploitation of natural fodder resources. However, climate change and associated effects are increasingly modifying agropastoral production systems and the rules of natural resource management by the populations [2]. These changes have been accentuated by ever-increasing population and growing housing needs, leading to an expansion of croplands at the expense of rangelands. The consequences are overgrazing, the extension of bare areas that threatened with many appetizing forage species [3].

The Bamboutos Mountains have not escaped this sad picture on deterioration of natural savannah resources $[1,4]$. Animal husbandry is practised extensively with fodder resources, coming essentially from natural vegetation which is subjected to many anthropic and ecological pressures. This overexploitation, combined with fluctuating rainfall and the rising of invasive weeds could negatively impact the natural rangelands productivity from a pastoral point of view. The evaluation of the floristic diversity and herbaceous production of these lands are important to guide the sustainable management of these pastures. The present study aims to assess the forage potential of the natural pastures in the Bamboutos Mountains (West Cameroon) with as specific objectives to characterise the floristic diversity and evaluate carrying capacity of the savannah rangeland.

Copyright: $\odot$ The authors. This article is open access and licensed under the terms of the Creative Commons Attribution License (http://creativecommons.org/licenses/by/4.0/) which permits unrestricted, use, distribution and reproduction in any medium, or format for any purpose, even commercially provided the work is properly cited. Attribution - You must give appropriate credit, provide a link to the license, and indicate if changes were made. 


\section{MATERIALS AND METHODS}

Study site: The study was carried out in the Eastern slope of the Bamboutos Mountains, West Cameroon between March and July 2017. The study area is located between $5^{\circ} 30^{\prime}-5^{\circ} 45^{\prime} \mathrm{N}$ and $10^{\circ} 03^{\prime}$ - $10^{\circ} 15^{\prime} \mathrm{E}$ (Figure 1). This mountain has a height of $2740 \mathrm{~m}$ and is one of the major volcanic mountains along the complex structure known as the Volcanic Line of Cameroon. The climate in the area is defined as Cameroonian altitude type, with a long rainy season (March-November) and a short dry season (December-February). The annual average rainfall varies according to the relief from 1750 to $2500 \mathrm{~mm}$ yearly. The annual average temperature varies from $10-12$ to $23.5^{\circ} \mathrm{C}$. The predominant soils are andosols, andic ferralitic soils and battleship ferralitic soils [5]. The herbaceous stratum is dominated by Pennisetum purpureum and Imperata cylindrica. The ligneous cover is strongly influenced by anthropogenic activities (agriculture and pasture) [1, 6].

\section{Data Collection}

Floristic inventory: The floristic survey was conducted between April and May 2017, in the early raining season characterised by active plants regrowth. The inventory was carried out using the quadrat points method aligned [7] in 15 plots of $20 \mathrm{~m} \mathrm{x}$ $20 \mathrm{~m}\left(400 \mathrm{~m}^{2}\right)$. Only the herbaceous plants and shrubs present were considered. Observations were made on lines materialized by two stakes between which a decametre was stretched over the roof of the herbaceous carpet. A vertical reading was taken every $20 \mathrm{~cm}$ along this decametre, using a metal rod with a tapered edge $1.5 \mathrm{~m}$ long. The total number of contact points was 100 . At each reading point, the contact of a species took place either through leaves or culms, and other organs, but the species were noted only once per reading point [8]. Four lines were arranged and each plot representing a homogeneous area.
Observations were made 3 months after the burning of the pastures. This makes it possible to determine the species eaten by cattle during this period.

Biological types: The biological types used are those defined by [9]: Therophytes (Th), Hemicryptophytes (He), Geophytes (Ge), Chamephytes (Ch) and Phanerophytes (Ph).

Phytogeographical types: The phytogeographical distribution types adopted corresponds to the major chorological subdivisions of [10] accepted for Africa. The main phytogeographical types adopted were as follows: Widespread species including: Cosmopolitan species (Cos); Pantropical species (Pan); Palaeotropical species (Pal); Afro-American species (AA). Species with African regional distribution including: AfroTropical species (AT); Sudano-Guinean species (SG); AfroMalagasy species (AM); African multi-regional species (PA); Sudano-Zambezian species (SZ); and Guineo-Congolese species (GC).

Pasture productivity: Following the morphological gradient (lowlands, mid-slopes and uplands), eight $25 \mathrm{~m}^{2}$ cutting plots were put in defences. These plots were fenced with barbed wire to protect against any grazing pressure [7]. Within each plot, 03 cuts at regular intervals of 30 days were made on areas of $1 \mathrm{~m}^{2}$ at $5 \mathrm{~cm}$ from the ground, as well as outdoors in adjacent control plots during the study period in order to better assess productivity [8]. Productivity was evaluated throughout the active life of the pasture by successive cutting that allowed a periodic estimation of primary productivity in $\mathrm{kg}$ of Dry Matter (DM) per day and per hectare ( $\mathrm{kg} \mathrm{DM} / \mathrm{d} / \mathrm{ha})$ [11]. Thus, the averages per cutting interval and per plot were obtained by dividing the production obtained by the number of days. March 4, 2017 was considered as the origin, since it was the date of the first rainfall. The first mowing was made

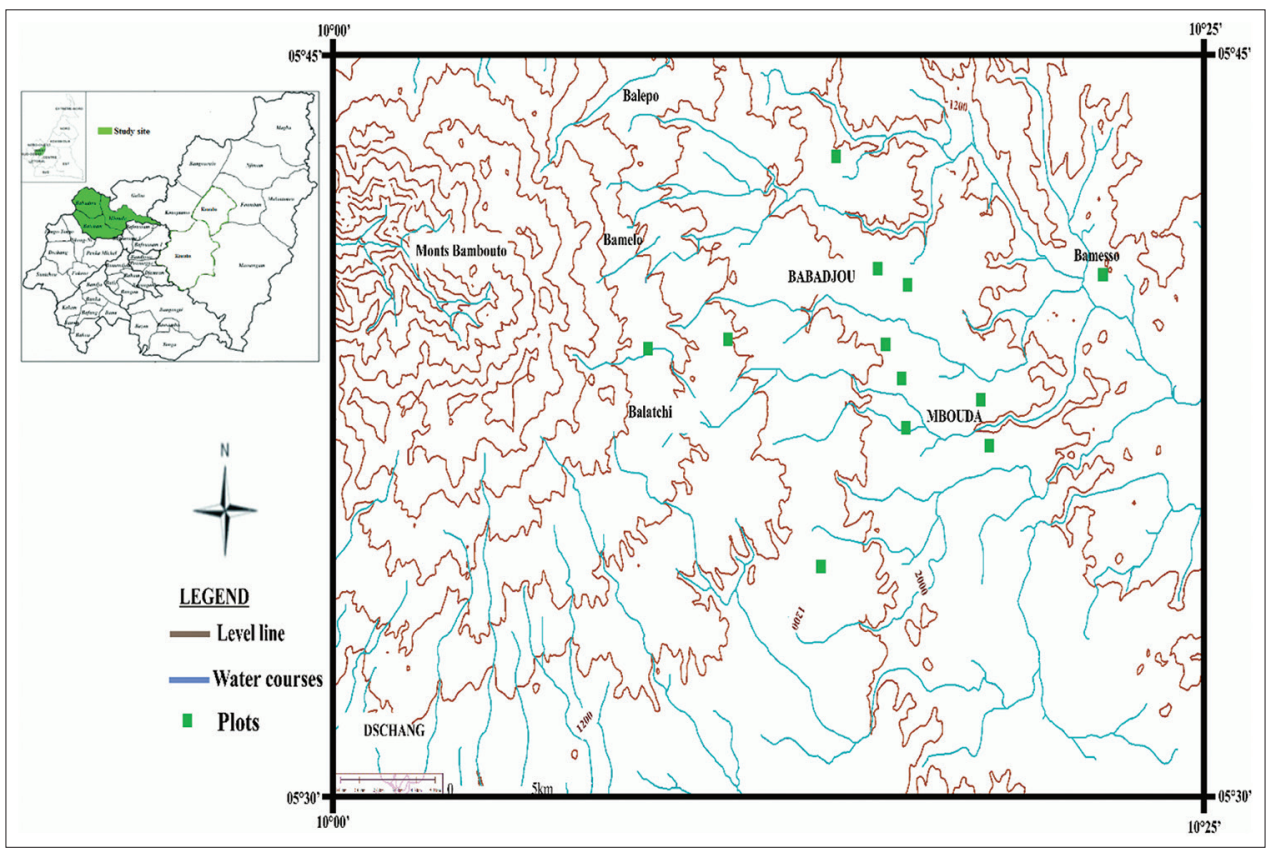

Figure 1: Location of the study area on the Bamboutos Mountains, West Cameroon 
81 days after the first rains and the last two mowings were made on the 24 June and the 24 July 2017 corresponding to 111 and 141 days after the first rains. The biomass obtained after each cut it was used for the estimation of the average daily productivity.

Herbaceous aerial phytomass: Herbaceous aerial phytomass was measured using the full harvest method. Measurements were made in two $1 \mathrm{~m}^{2}$ plots selected at random from each 25 $\mathrm{m}^{2}$ plot. In the eight plots selected for the study, a total of 16 plots of $1 \mathrm{~m}^{2}$ were sampled. Above-ground parts of the plants were cut off at ground level with a sickle. Plant samples of fresh material from each group were brought back to the laboratory for drying in an oven at $80{ }^{\circ} \mathrm{C}$ until a constant weight of dry matter was obtained. The average phytomass was calculated for all plots. This average phytomass obtained was used to calculate the carrying capacity of the pasture.

\section{Data Analysis}

Floristic data on species found in the savannah rangeland of the Mount Bamboutos were submitted to content and descriptive analysis and the following parameters were computed: frequencies of species, contributions of species and floristic diversity indices.

The frequency of a species i $(\mathrm{SFi}): \mathrm{SFi}(\%)=100 \times n \mathrm{n} / \mathrm{N}$

The specific contribution of a species i (SCi): SCi $(\%)=100$ $\times \mathrm{ni} / \sum \mathrm{ni}$

Where ni $=$ Number of points where species i was encountered, $\mathrm{N}=$ Total number of points.

The pastoral value (PV) (Daget and Poissonet, 1971): PV $=0.25 \times \Sigma$ SCi $\times$ Sli.

Where SI = Specific quality index chosen on a scale of 0 to 4 . $\mathrm{SCi}=$ Specific Contribution of Contact.

The grazing value of a pasture depends on the proportion of fodder species eaten by the livestock Diversity indices were computed as follows:

Maximum diversity: $\mathrm{Hmax}=\log _{2} \mathrm{~S}$; Where S: total number of species inventored;

Shannon-Weaver Diversity Index (H'): H'= - $\mathrm{SF}$ x x $\log _{2} \mathrm{SFi}$

Where SFi is the frequency of any species i found in the studied area specific.

Shannon-Weaver Diversity Index (H'): H'= - $\mathrm{SF}$ i x $\log _{2} \mathrm{SFi}$

Where SFi is the specific frequency.

The Pielou equitability index (Eq): Eq = H'/Hmax
Carrying Capacity: The carrying capacity at the study period was calculated according to the formula: Carrying Capacity: CC $($ TLU/ha/year $)=$ Production $(\mathrm{kg} \mathrm{DM} / \mathrm{ha}) \times$ k/ $6.25(\mathrm{~kg} \mathrm{DM} / \mathrm{TLU}) \times$ useful life.

$\mathrm{k}=1 / 3$ : Consumable fraction, 6.25: daily consumption of the TLU (Tropical Livestock Unit) expressed in kg DM/d). Grazing was used for 148 days, from March 4, 2017 when the first rains arrived to July 30, 2017 when the study ended.

\section{RESULTS}

\section{Floristic Composition}

In this study, 74 species including 09 woody plant species belonging to 56 genera and 20 families (APGIII) were recorded. The richest family was Poaceae with 22 species representing $30.13 \%$ of the total number of species surveyed, followed by Fabaceae (11 species, 15.06\%), Asteraceae (8 species, 10.95\%) and Cyperaceae (7 species, 9.58\%). Eight families were represented by only one species. The most frequent species were: Cassia mimozoides (93.33\%), Chromolaena odorata (86.66\%), Aspilia africana (80\%), Imperata cylindrica (80\%), Loudetia camerunensis (80\%), Annona senegalensis (73.33\%), Dissotis princeps $(73.33 \%)$ and Stenotaphrum secundatum (73.33\%). The species with the highest specific occurrence contributions were: Imperata cylindrica (17.45\%), Setaria barbata (10.84\%), Stenotaphrum secundatum (7.96\%) Brachiaria Rhuziziensis (6.72\%), Pennisetum polystachion (6,05\%), Andropogon lacunosus (5.36\%), Polystichum aculeatum (4.91\%), Calopogonium mucunoides (4.08\%) and Loudetia camerunensis $(3.68 \%)$.

\section{Floristic Diversity}

The species richness of the plots varies from 11 to 36 species, with a maximum diversity ranging from 3.45 to 5.17 (Table 1). In some the studied plots, diversity indices values were high. Shannon diversity index values ranged from 0.57 to 3.77 and Pielou equitability values range from 0.16 to 0.76 .

\section{Specific Quality Index and Pastoral Value}

Fodder species with a specific quality index of 5 contributed $20 \%$ to the average grazing value of the pasture. Those with poor pasture value contributed $1.76 \%$. 25 species were not included in the calculation of pasture value because they were not eaten by animals. The pastoral value of the rangeland obtained by combining the specific quality indices and the specific contribution of each species inventoried was $56.21 \%$ (Table 2). Stylosanthes hamata was the most abundant Fabaceae, this leguminous fodder species represented $4.76 \%$ of the total species inventoried. According to the herdsmen, the species is not appetible for cattle. The other Fabaceae of the rangeland, such as Entada africana, Cassia mimozoides and Indigofera mimosoides were also poorly palatable for livestock. 
Table 1: Diversity indices values for plant community of the savannah rangeland of the Bamboutos Mountains

\begin{tabular}{lcccc}
\hline Plots & $\begin{array}{c}\text { Species } \\
\text { richeness }(\mathrm{S})\end{array}$ & $\begin{array}{c}\text { Maximum } \\
\text { diversity }(\mathrm{Hmax})\end{array}$ & $\begin{array}{c}\text { Shannon } \\
\text { index }\left(\mathrm{H}^{\prime}\right)\end{array}$ & $\begin{array}{c}\text { Pielou } \\
\text { Equitability }(\mathrm{Eq})\end{array}$ \\
\hline Plot 1 & 11 & 3.45 & 0.57 & 0.16 \\
Plot 2 & 16 & 4 & 2.27 & 0.56 \\
Plot 3 & 12 & 3.58 & 1.64 & 0.45 \\
Plot 4 & 18 & 4.17 & 2.91 & 0.69 \\
Plot 5 & 22 & 4.45 & 2.48 & 0.55 \\
Plot 6 & 24 & 4.58 & 3.49 & 0.76 \\
Plot 7 & 36 & 5.17 & 3.76 & 0.72 \\
Plot 8 & 31 & 4.95 & 3.63 & 0.73 \\
Plot 9 & 21 & 4.39 & 3.49 & 0.79 \\
Plot 10 & 34 & 5.08 & 3.52 & 0.69 \\
Plot 11 & 29 & 4.85 & 3.68 & 0.75 \\
Plot 12 & 16 & 4 & 2.63 & 0.65 \\
Plot 13 & 25 & 4.64 & 3.18 & 0.68 \\
Plot 14 & 11 & 3.45 & 1.7 & 0.49 \\
Plot 15 & 26 & 4.7 & 3.38 & 0.72 \\
\hline
\end{tabular}

\section{Biological Types}

The raw spectrum of Raunkiaer's biological types estimated from the species richness shows that phanerophytes dominate largely in the site (29.72\%), followed by therophytes (24.32\%), hemicryptophytes (20.27\%) and chamephytes (18.91\%) (Figure 2).

\section{Phytogeographic Types}

The overall phytogeographic analysis shows that Afro-Tropical species were the most dominant $(24.02 \%)$, followed by pantropical (18.91\%) and paleotropical (13.51\%) species (Figure 3). Afro-Malagasy and Afro-American species are poorly represented.

\section{Productivity}

The dry matter production was high during the first cut (81 days since the first rain), decreased at the second mowing and increased in each vegetation unit from the third mowing onwards (Figure 4). The plot dominated by Pennisetum purpureum (plot 8) produced the highest dry biomass at the first mowing, this production decreased considerably over time. The Plot 4 had the highest dry matter at the third mowing.

\section{Aerial Herbaceous Phytomass and Carrying Capacity}

The values of the herbaceous phytomass studied range from 2917.3 to $16900 \mathrm{~kg} \mathrm{DM} / \mathrm{ha}$ in the fenced (defended) plots and vary from 1320 to $15508 \mathrm{~kg} \mathrm{DM} /$ ha in the outdoor (unfenced) plots (Figure 5). Plot 8 was the least palatable while plot 7 was the most palatable outdoors. The average biomass obtained inside the different plots was $6498.57 \mathrm{~kg} \mathrm{DM} / \mathrm{ha}$ and the carrying capacity of the rangeland was $2.31 \mathrm{TLU} / \mathrm{ha}$.

\section{DISCUSSION}

Floristic composition of the routes: The above results indicate that natural pastures studied are dominated by grasses. Indeed,
Table 2: Specific quality index and gross pastoral value of the plant Species in the savannah rangeland of the Bamboutos Mountains

\begin{tabular}{lcc}
\hline Appetence Index & Quality index & Pastoral value (\%) \\
\hline Poor pastoral value & 1 & 1.76 \\
Average value & 2 & 5.87 \\
Fairly good value & 3 & 9.02 \\
Good value & 4 & 19.04 \\
Very good value & 5 & 20.52 \\
Pastoral value of grazing & & 56.21 \\
\hline
\end{tabular}

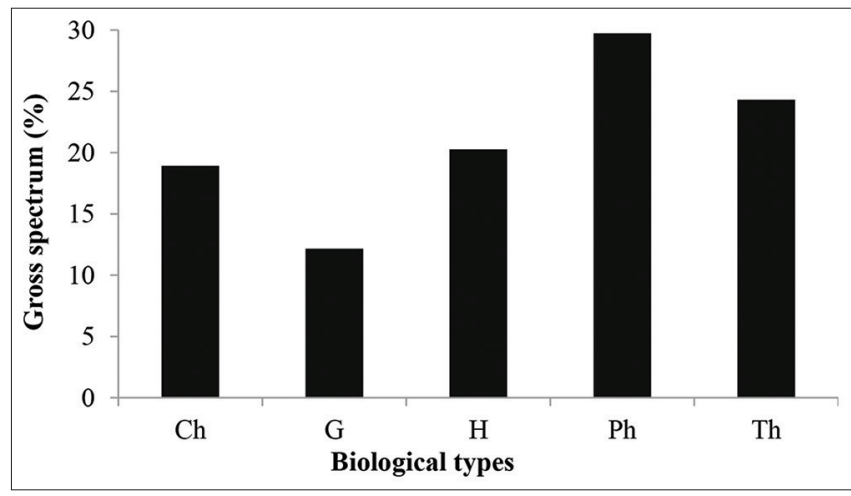

Figure 2: Distribution of the biological spectrum of species in the natural pastures in the Bamboutos Mountains. chamephytes (Ch), geophytes $(\mathrm{Ge})$, hemicryptophytes $(\mathrm{He})$, phanerophytes $(\mathrm{Ph})$, therophytes $(\mathrm{Th})$

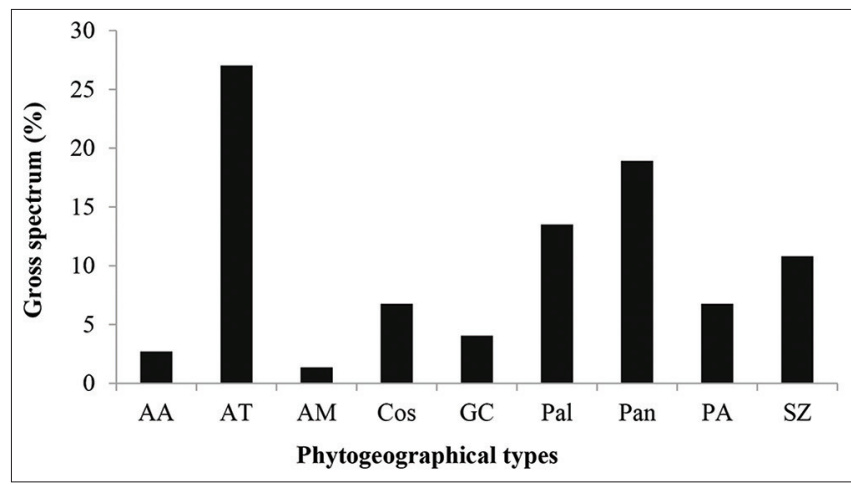

Figure 3: Detailed phytogeographic spectrum of species in natural pastures of the Bamboutos Mountains. Afro-American species (AA), Afro-Tropical species (AT), Afro-Malagasy species (AM), Cosmopolitan species (Cos), Guineo-Congolese species (GC), Palaeotropical species (Pal), Pantropical species (Pan), African multi-regional species (PA), Sudano-Zambezian species (SZ)

the value of a pasture depends on its Poaceae content as they are the most productive and most appetizing for livestock [12, 13]. The work of $[1,6]$ states that the high presence of species of the Gramineae family is explained by the fact that savannahs are grassdominated ecosystems. Moreover, Poaceae taxa have a high tilling potential and a high regrowth rate after grazing if environmental conditions are favourable. This observation is similar to that of [14] for their floristic study near Abidjan in Ivory Coast.

Nine species showed the highest specific contributions of occurrence. These species contribute significantly to the cover of the herbaceous canopy and the herbaceous phytomass. The 
high contribution of Imperata cylindrica in these pastures could be explained by its ability to multiply through the stolons and its strong capacity to adapt to arid environments imposed by frequent fires and drought. Overall, this predominance of annual grasses could also justify the fodder deficit after the rainy season because many of them are totally destroyed by bush fires which occur during the dry season. Moreover, [15] argue that the decline in grass growth is linked to the fact that many annual grasses wilt and die after fruiting.

Floristic diversity of the rangelands: The difference in the floristic composition of the different plots could be linked to the variations in ecological and climatic conditions among which are inter and intraspecific competition, soil fertility and depth, as well as animal pressures and anthropogenic factors. The values of the Shannon-Weaver diversity index range from 0.57 to 3.76 and the Pielou equitability between 0.16 and 0.76. [21] obtained Shannon-Weaver diversity index values ranging from 0.81 to 1.43 and Pielou equitability ranging from 0.38 to 0.42 in savannah pasture. The values found by these authors are slightly lower than those found in the Bamboutos Mountains natural pastures. The

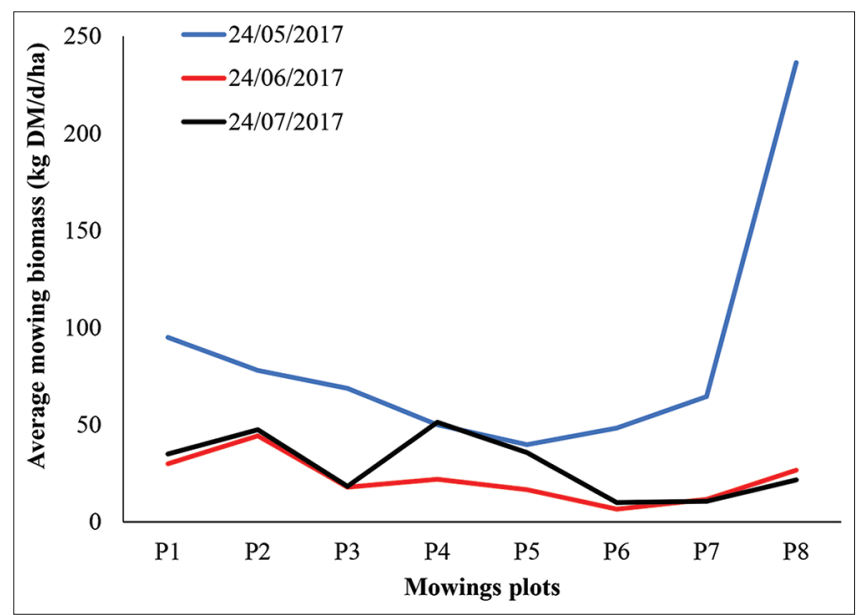

Figure 4: Average mowing biomass (kg DM/d/ha) by plot and mowing period difference in these results could be explained by the difference in the vegetative stages during which the assessment of floristic diversity was done and the observed biotope diversity (lowland, hilltop and slope zone). These results show that the vegetation in the natural pastures of the Bamboutos Mountains is very diverse with an equitable distribution of species.

Pasture quality and forage value: Pasture quality depends on the proportion of grasses that are the most productive and most palatable for targeted livestock. The herbaceous carpet of the studied savannas is mainly made of grasses that develop large clumps (Andropogon lima, Brachiaria Rhuziziensis, Heteropogon contortus Hyparrhenia involucrata, Loudetia arundinacea, Panicum maximum, Panicum laxum, Paspalum conjugatum, Pennisetum polystachion, Pennisetum purpureum and Setaria barbata. The presence of leguminous forage is an appreciable indicator of the quality of the rangelands (Desmodium adscendens, Calopogonoium mucunoides and Indigofera mimosoides). Indeed, the nitrogen content of these leguminous species is a source of protein needed for a nutritionally balanced feed [16]. It is also an indicator of ecological imbalance due to high grazing pressure or an unfavourable climatic season. However, many of these leguminous plants are reported for their high level of tannins and low digestibility [17]. Meanwhile, fodder species other than grasses and leguminous, which are not very palatable and provide little energy to the livestock, such as Hibiscus asper and Mariscus cylindristachyus were cited as being an excellent fodder by herdsmen.

The pastoral value of a pasture is a function of the proportion of forage species eaten by the livestock. The pastoral value of $56.21 \%$ obtained in this study is relatively high compared to the $26.8 \%$ found by [18] in northern Benin, and comparable to the $53.3 \%$ obtained by [11] in the Adamaoua savanna in Cameroon. The difference in pastoral value could be explained by a severe degradation of the pasture, with the Poaceae being replaced by annual non-fodder species. According to [19], a pasture is of good quality if its pastoral value reaches 65\%. Therefore, the gross pastoral value of the Bamboutos Mountains rangeland indicates that the pasture was not of good quality. In general,

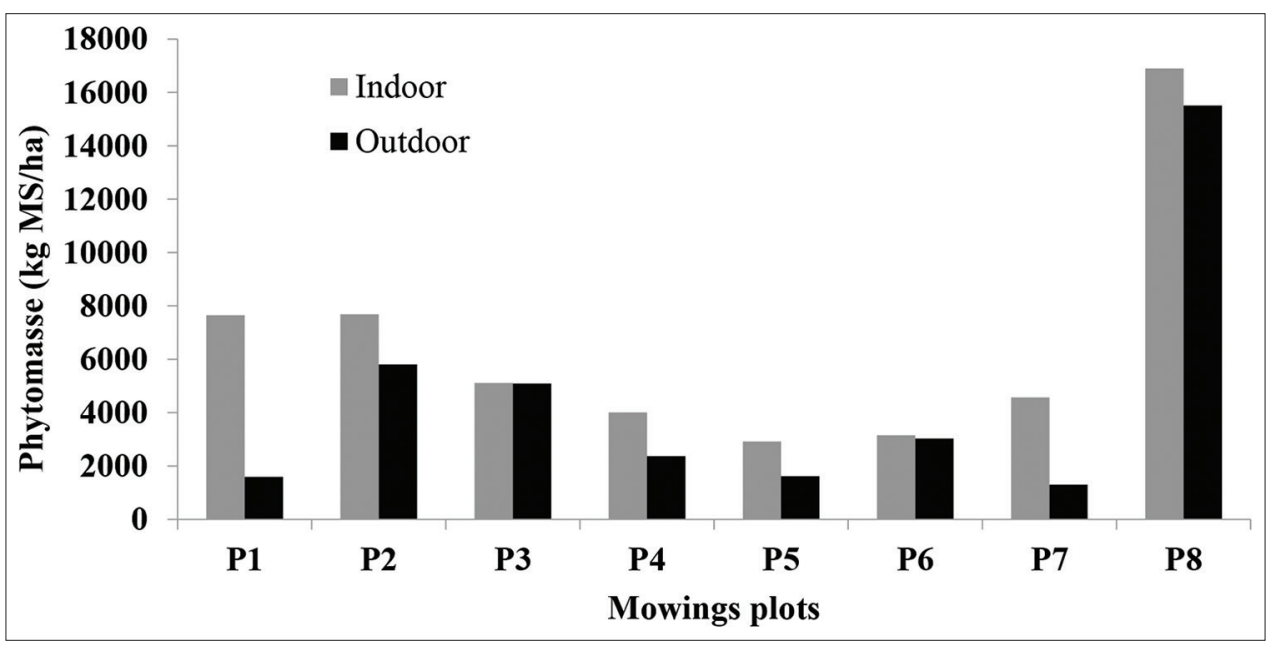

Figure 5: Total herbaceous phytomass in the savannah rangeland of the Mount Bamboutos at the end of the active vegetation period 
the pastoral value of pastures decreases with increasing grazing pressure due to the decrease in the contribution of good forage species [2]. The high frequency of poor quality fodder plants as well as occurrence of invasive species such as Stylosanthes hamata and unappetizing species such as Ageratum conyzoides, Aspilia africana, Chromolaena odorata, Sida acuta ... could explain this poor pastoral value obtained. Regular bush fires also contribute in reducing the pastoral value of a pasture because they favour the development of annuals to the detriment of perennials [20]. Some of the woody plants such as Psorospermum senegalense and Annona senegalensis found in the Bamboutos Mountains natural pasture have been reported to be palatable; though the palatability is very low and only observed during the lean season.

Biological and phytogeographical types: The main biological types found in the studied natural pastures were phanerophytes and therophytes. Similar results were obtained by [22] in the grazed vegetation of the Guinean zone in Togo and [4] in the Bambouto and Mbapit mountains in Cameroon. In fact, phanerophytes reflect the adaptive stage of plants following a competitive strategy. Phanerophytes are a strategy for adapting to unfavourable conditions and a form of resistance to climatic rigours. The high proportion of widely distributed taxa indeed reflects the opening of this flora to external influences or may be an indication of degradation, as the flora loses its specificity [23]. These species are most often ruderals or species from disturbed environments [4]. This disturbance could be due to the pressure of pastures.

Herbaceous phytomass and carrying capacity: The high production obtained from plot 8 is comparable to the value found by [8] in the Guinean zone, where certain regions could produce more than $15 \mathrm{t} \mathrm{DM} / \mathrm{ha}$. This high production could be related to the dominance of Pennisetum purpureum in the Bamboutos Mountains pasture. This difference with our study site can be explained by the fact that these soils benefit from an organic fertilizer supply via animal excreta on the grazing area and the species' high capacity to regrow. In fact, the floristic inventories revealed a strong presence of plants belonging to the non-appetizable groups, indicating the high pressure on the palatable species. Also, the abundance of species in the plots with easy access means that animals prefer to graze in the lower slopes, leaving certain areas free, such as the upper slopes from which the high production is derived. The low biomass value outside some plots could be explained by the high palatability and pasture value of these plots. In fact, such plots were dominated by Brachiaria rhuziziensis which regrowth at juvenile stage is highly palatable for livestock.

The carrying capacity value of $2.31 \mathrm{TLU} / \mathrm{ha}$ obtained in this study is higher than those observed by [24] 0,37 TLU/ha/year in Mali, [11] in other savanna rangeland in Cameroon 1.8 TLU/ ha and [14] in Ivory Coast 0.9 TLU/ha. This difference could be explained by the abundance of certain species (Sida acuta) that are not or very poorly palatable for animals, which tend to increase the total production obtained at the end of the active period. Also, the presence of species with high production potential such as Brachiaria rhuziziensis and Pennisetum purpureum could explain this high capacity of the pasture to efficiently maintain a high number of cattle per hectare.

\section{CONCLUSION}

The flora of the natural pastures in the Bamboutos Mountains is dominated by the families Poaceae, Fabaceae, Asteraceae and Cyperaceae. Imperata cylindrica, Setaria barbata, Stenotaphrum secundatum, Brachiaria Rhuziziensis and Pennisetum polystachion were the most abundant species. The values of different diversity indices showed that these natural pastures are diversified and the distribution of species is equitable. The production of phytomass in protected conditions (defenced) is higher than in grazed conditions and the carrying capacity of the grazing area is high for 148 days of grazing. The availability of fodder resource is seasonal and that dictates the surge of the animals according to these seasons. Good sustainable management of these pastures requires the restoration of degraded areas, securing livestock feed and conflict management.

\section{ACKNOWLEDGEMENTS}

The authors thank herdsmen for their collaboration in data collection.

\section{CONFLICT OF INTEREST}

The authors declare that they have no conflict of interest.

\section{REFERENCES}

1. Wouokoue TJB, Nguetsop VF, Fonkou T. Floristic diversity of Western Highlands savannas of Cameroon. International Journal of Current Research in Biosciences and Plant Biology. 2017; 4: 7-13

2. Boton-Liehoun E, Daget P, César J. Activités de pâturage, biodiversité et végétation pastorale dans la zone ouest du Burkina Faso. Revue d'élevage et de médecine vétérinaire des pays tropicaux. 2006 ; 59 $(1-4): 31-38$.

3. Yameogo G, Kiema A, Yelemou, B, Ouedraogo L. Caractéristiques des ressources fourragères herbacées des pâturages naturels du terroir de Vipalogo (Burkina Faso). International Journal of Biological and Chemical Sciences. 2013 ; 7(5): 2078-2091

4. Wouokoue TJB. Phytosociologie des monts Bambouto et Mbapit, équations allométriques pour l'estimation de la biomasse aérienne des ligneux des savanes. Thèse de Doctorat/Ph.D, Université de Dschang. 2018; 229P

5. Tematio P, Kengni L, Bitom D, Hodson M, Fopoussi JC. Soils and their distribution on Bambouto volcanic mountain, West Cameroon Highland, Central Africa. Journal of Africa Earth Sciences. 2004; 39: 447-457.

6. Wouokoue TJB, Anjah GM, Nguetsop VF, Fonkou T., Floristic diversity of the savannah ecosystems in three altitudinal zones of the Bambouto Mountains, West Cameroon. Cameroon Journal of Biological and Biochemical Sciences. 2017; 25: 52-59.

7. Daget P, Poissonnet J. Une méthode d'analyse phytosociologique des prairies. Critères d'application. Annales Agronomiques. 1971 ; 22 (I) : 5-41.

8. Boudet G. Pâturages tropicaux et les cultures fourragères. Ministère de la coopération française. EMVT Paris, $1991 ; 261 \mathrm{p}$

9. Raunkiaer C. The life forms of plants and statistical plant geography. Clarendon Press, Oxford, London, 1934; 632p

10. White F. The vegetation of Africa. A descriptive memoir to accompany the Unesco/Aetfat/Unso vegetation map of Africa. UNESCO, Natural Ressouces Research, 20: 1983 ; 356p 
11. Yonkeu S. Végétation des pâturages de l'Adamaoua (Cameroun). Ecologie et potentialités pastorales. Thèse d'Université. Université Rennes1. 1993 ; 207p

12. Cesar J. Etude de la production biologique des savanes de la Côte d'Ivoire et son utilisation par I'homme. Biomasse, valeur pastorale et production fourragère. Thèse Doctorat d'Etat, Université Pierre et Marie Curie, Paris, France, $1992 ; 672 p$

13. Fournier A. Phénologie, croissance et production végétales dans quelques savanes d'Afrique de l'Ouest. Variation selon un gradient climatique. Thèse Doctorat d'Etat, Université Pierre et Marie Curie, Paris, France $1991 ; 312 p$

14. Kouassi AF, Koffi KJ, N'Goran KSB, Ipou IJ. Potentiel de production fourragère d'une zone pâturée menacée de destruction : cas du cordon littoral Port Bouët et Grand Bassam. Journal of Applied Biosciences. $2014 ; 82$ : 7403-7410

15. Hiernaux P, LeHouerou HN. Les parcous du sahel. Secheresse. 2006 ; $17(1-2): 51-71$

16. Adjolohoun S, Buldgen A, Adandedjan C, Decruyenaere V, Dardenne P. Yield and nutritive value of herbaceous and browse forage legumes in the Borgou of Benin. Tropical Grasslands. 2008; 42(2):104-111

17. Addisu SH. Effect of dietary tannin source feeds on Ruminal fermentation and production of cattle; a review. Online Journal of Animal Feed Resources. 2016; 6(2): 45-56.

18. Lesse P, Houinato M, Azihou F, Djenontin J, Sinsin B. Typologie, productivité, capacité de charge et valeur pastorale des pâturages des parcours transhumants au Nord Est de la République du Bénin.
International Journal of Innovation and Applied Studies. 2016 ; 14(1) 132-150

19. Daget P, Godron M. Pastoralisme. Troupeaux, espaces et société Hatier - AUPELF IUREF, 1995 ; 510p

20. Sawadogo L, Tiveau D, Nygard R. Influence of selective cutting, livestock and prescribed lire on herbaceous biomass in the savannah woodlands of Burkina Faso, West Africa. Agriculture, Ecosystems and Environment. $2005: 105: 335-345$.

21. Amboua IO, Assongba YF, Yoka J, Akouango P, Djego JG. Effet des arbustes sur la diversité floristique et la production herbacée dans les pâturages au ranch d’Essimbi à Boundji (République du Congo) Journal of Applied Biosciences. 2019 ; 134: 13618 - 13629

22. Amegnaglo KB, Dourma M, Akpavi S, Akodewou A, Wala K, Diwedigab, Atakpama W, Agbodan KML, Batawila K, Akpagana K. Caractérisation des formations végétales pâturées de la zone guinéenne du Togo : typologie, évaluation de la biomasse, diversité, valeur fourragère et régénération. International Journal of Biological and Chemical Sciences. 2018 ; 12(5): 2065-2084

23. Devineau JL, Fournier A., La flore et la végétation. In: Devineau J.L., Fournier A., Kaloga B (eds.), Les sols et la végétation de la région de Bondoukuy (Ouest Burkinabé), présentation générale et cartographie préliminaire par télédétection satellitaire (SPOT), ORSTOM éditions. $1997 ; 29-47$

24. Assarki H. La gestion pastorale : Evaluation du potentiel fourrager dans la commune rurale de Madiama. Mémoire de fin de cycle IPR/ IFRA de Katibougou ; République du Mali, 2000 ; 70p 